\title{
Elazı̆̆ Keban Baraj Gölü Pertek Bölgesi Su Kalitesinin Bazı Parametrelerle Belirlenmesi
}

\author{
Murat TOPAL* \\ Munzur Üniversitesi, Mühendislik Fakültesi, Çevre Mühendisliği Bölümü, Tunceli \\ (ORCID: 0000-0003-0222-5409)
}

\begin{abstract}
$\ddot{O} z$
Bu çalışmada, Keban Baraj Gölü Pertek Bölgesinden yerüstü su numuneleri 2018 yılı yaz mevsimi boyunca alındı ve Yerüstü Su Kalitesi Yönetmeliği’nde (YSKY) verilen su kalite parametreleriyle karşılaştırıldı. Elde edilen verilere göre $\mathrm{pH} 8,7-8,84$ arasında, sicaklık $20,1-27,5^{\circ} \mathrm{C}$ arasında, elektriksel iletkenlik (Eİ) $264-398 \mu \mathrm{S} / \mathrm{cm}$ arasında, nitrat $\left(\mathrm{NO}_{3}^{-}-\mathrm{N}\right)$ konsantrasyonları 1,1-1,34 $\mathrm{mg} / \mathrm{L}$ arasında, Biyokimyasal Oksijen İhtiyac1 (BOİ) konsantrasyonları 2,3-3,6 mg/L arasında ve Kimyasal Oksijen İhtiyac1 (KOİ) konsantrasyonları 25,2-33 mg/L arasında değerler aldığı belirlendi. Sonuç olarak, Keban Baraj Gölü Pertek Bölgesinden alınan yerüstü sularının pH, sıcaklık, Eİ, $\mathrm{NO}_{3}^{-}-\mathrm{N}, \mathrm{BOI்}_{5}$ konsantrasyonları açısından Sınıf-1 kalitesinde su olduğu, KOİ açısından ise Sınıf2 kalitesinden su olduğu tespit edildi.
\end{abstract}

Anahtar kelimeler: Su kalitesi, Göl, Yerüstü suları, Pertek, Elazığ.

\section{Determination of the Water Quality with some Parameters in Elazig Keban Dam Lake Pertek Region}

\begin{abstract}
In this study, surface water samples from Keban Dam Lake Pertek Region were taken during the summer of 2018 and compared with the water quality parameters given in the Surface Water Quality Regulation (SWQR). According to the obtained data, $\mathrm{pH} 8.7-8.84$, temperature between $20.1-27.5^{\circ} \mathrm{C}$, electrical conductivity (EC) 264$398 \mu \mathrm{S} / \mathrm{cm}$, nitrate $\left(\mathrm{NO}_{3}{ }^{-}-\mathrm{N}\right)$ concentrations between 1.1-1.34 mg/L, Biochemical Oxygen Demand $\left(\mathrm{BOD}_{5}\right)$ concentrations 2.3-3.6 mg/L and Chemical Oxygen Demand (COD) concentrations were determined to be between 25.2-33 mg/L. As a result, the surface waters taken from the Pertek Region of Keban Dam Lake were found to be water in Class-1 quality in terms of $\mathrm{pH}$, temperature, $\mathrm{EC}, \mathrm{NO}_{3}^{-}-\mathrm{N}, \mathrm{BOD}_{5}$ concentrations, and water from Class-2 quality in terms of COD.
\end{abstract}

Keywords: Water quality, Lake, Surface water, Pertek, Elazig.

\section{Giriş}

2050 yılında 9 milyara ulaşması beklenen global popülasyonun hızla artışına yetecek tarımsal üretimi (gıda ve iplik gibi) sağlamak için ekin alanları hızla artmaktadır [1,2,3]. Bununla beraber, iklim değişikliği etkileri kadar kentleşme ve kirlenmeye bağlı olarak temiz su kaynaklarının eksikliği de temel bir darboğazdır $[3,4]$. Ayrıca, suyun düşük değerli olan sulamada kullanımındansa yüksek değerli olan endüstriyel, evsel ve hidroelektrik kullanımları tercih edilmektedir. Bu da tarımın performansı üzerine ilave baskılara yol açmaktadır $[3,5,6]$.

Su kaynakları gerekli sulama ihtiyacını karşılamak için uygun olmadığında gıda güvenliği asla garanti edilemez. Bu problem, popülasyonun hızlı artışı ve tarıma yüksek bağımlılık ile çoğu ülkede giderek daha ciddi hale gelmektedir [7]. Sulama suyu kıtlığı problemini çözmek için, yüzey suyu ve yeraltı suyu sulama için kullanılmaktadır. Bununla beraber yoğun tarım aktiviteleri, yüzey suyu kıtlığına

*Sorumlu yazar: murattopal@munzur.edu.tr

Geliş Tarihi: 26.10.2018, Kabul Tarihi: 12.03.2019 
bağlı olarak yeraltı suyuna olan ihtiyacı arttırmaktadır. Bu durum da yeraltı suyu tablasının azalması ve tuzlulaşma gibi birçok çevre problemine yol açmaktadır $[3,8]$.

Dünyada en büyük su kullanıcısının tarım sektörü olduğu [9] göz önüne alınarak, bu sektörde suyun kullanımının ve yönetiminin yeniden düşünülmesi zorunludur [10]. Su yönetiminin değerlendirilmesi, su kaynaklarının uygunluğunun tespiti için gittikçe daha önemli olmaktadır. Bu durum, özellikle bu kaynaklar için rekabetin en yüksek olduğu ve 21.yy. boyunca da artmasının beklendiği kurak çevrelerde önemli hale gelmektedir [10]. Bugüne kadar yapılan iklim çalışmaları, Akdeniz çevresinde su kaynaklarının uygunluğunun azalacağını öngörmektedir. Yağışlardaki azalma ve sıcaklıklardaki artış [11,12] bölgesel su dengesi üzerinde belirgin sonuçlara yol açacaktır [10]. Avrupanın kıyısında yer alan Akdeniz' de su kaynakları yönetimi, değişken yağmur durumlarına ve yüksek sulama ihtiyacına bağlı olarak çeşitli mücadelelerle karşılaşmaktadır $[13,14,15]$. Bu bölgede uygun su kaynaklarını azaltan daha sıcak ve kurak şartlar nedeniyle iklimin gelecekte değişeceği düşünülmektedir [15,16-18]. Bu nedenlerle, tarımsal amaçla kullanılacak olan suların su kalitelerinin sürekli olarak izlenmesi gerekmektedir.

Ülkemizde su kaynaklarının iyi yönetilmesi gerekmektedir. Bu çerçevede, su kaynaklarının yönetiminde en önemli yapılar barajlar ve göletlerdir. Barajlar sayesinde hem içme hem de sulama amaçlı su ihtiyacı karşılanabilmektedir. Ancak, söz konusu suların içme veya sulama suyu olarak kullanılabilmesi için su kalitesinin belirlenmesi, yönetmeliklerimizde verilen değerlere uyması ve sürekli izlenmesi gerekmektedir. Bu çalışmada, önemli baraj göllerimizden olan Keban Baraj Gölü Pertek Bölgesinde su kalitesinin mevcut durumu ve su kalite sınıfı bazı parametrelerle ortaya konulmuştur.

\section{Materyal ve Metot}

\subsection{Materyal}

Bu çalışmada, yerüstü su numuneleri Elazığ ili, Keban Baraj Gölü, Pertek Feribot İskelesi mevkiinden alındı ve bu bölge çalışma alanı olarak seçildi (Şekil 1). Pertek feribot İskelesi mevkiinin seçilme nedeni göl üzerinde alabalık tesislerinin, yerleşim yerlerinin bulunması ve feribot işletmesi olması nedeniyle bu bölgenin antropojenik etkilere maruz kalmasıdır. Ayrıca, bu bölgeden sulama suyu amacıyla su çekilmekte ve sulama amaçlıda kullanılmaktadır. Bu amaçla, Keban Baraj Gölü Pertek bölgesinden yerüstü su numuneleri 2018 yılı Haziran, Temmuz ve Ağustos aylarında 10 günde bir kompozit numune olacak şekilde 3 farklı örnekleme noktasından alındı. Numune alma noktalarına ait ED50 3 derecelik koordinatlar Tablo 1'de verilmiştir. Alınan yerüstü su numuneleri numune kaplarına aktarıldı. Numunelerde pH, sıcaklık, elektriksel iletkenlik (EI), Kimyasal Oksijen İhtiyacı (KOİ), nitrat $\left(\mathrm{NO}_{3}{ }^{-}-\mathrm{N}\right)$, Biyolojik Oksijen İhtiyacı (BOİ) parametreleri analiz edildi. Bu çalışmada, yaz mevsiminin (Haziran, Temmuz ve Ağustos aylarında) seçilme nedeni tarımsal faaliyetlerin yoğun olması nedeniyle Keban Baraj Gölü'nden su çekilerek sulama suyu ve kullanma suyu olarak değerlendirilmesidir.

Tablo 1. Numune alma noktalarına ait koordinatlar

\begin{tabular}{|c|c|c|}
\hline \multirow{2}{*}{ Noktalar } & \multicolumn{2}{|c|}{ Koordinatlar* $^{*}$} \\
\cline { 2 - 3 } & $\mathbf{X}$ & Y \\
\hline $\mathbf{N}-1$ & 523664 & 4298019 \\
\hline $\mathbf{N}-2$ & 524554 & 4298627 \\
\hline $\mathbf{N}-3$ & 525415 & 4299252 \\
\hline
\end{tabular}

*Koordinatlar Magellan eXplorist 510 (Santa Clara, USA) cihazı kullanılarak elde edilmiştir. 


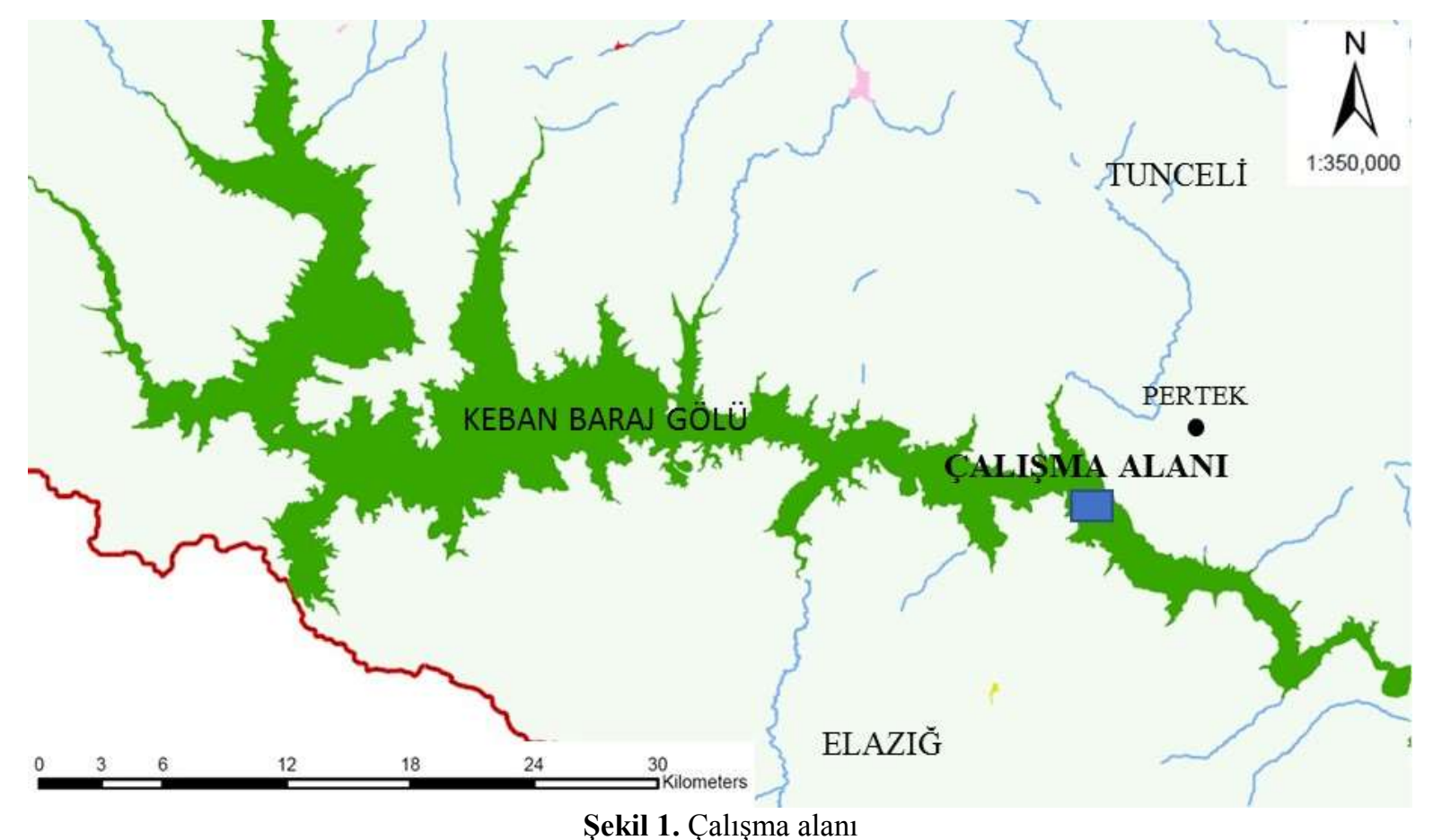

\subsection{Metot}

Çalışmada, pH, sıcaklık ve Eİ değerleri ile $\mathrm{KOI}, \mathrm{BOI}_{5}, \mathrm{NO}_{3}{ }^{-}-\mathrm{N}$ parametreleri analizlendi. Yerüstü su numunelerinin $\mathrm{pH}$, sıcaklık ve Eİ değerleri Hach Lange $30 \mathrm{~d} \mathrm{pH}$, elektriksel iletkenlik ve çözünmüş

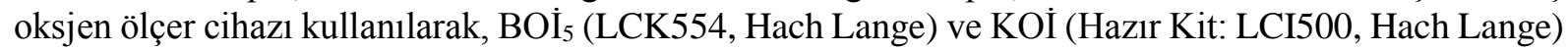
konsantrasyonları Hach Lange DR3800 model spektrofotometre ile spektrofotometrik yöntem kullanılarak tespit edildi. $\mathrm{NO}_{3}{ }^{-} \mathrm{N}$ (Hazır Kit: Nova60-14987, Merck) konsantrasyonları ise Nova60 model spektrofotometre ile spektrofotometrik yöntem kullanılarak tespit edildi.

\section{3. İstatistiksel analizler}

Çalışmamızda her bir numune için analizler 3 paralel olacak şekilde gerçekleştirildi ve elde edilen verilerin ortalaması alınarak standart hata değerleri grafiklerde gösterildi.

\section{Bulgular ve Tartışma}

Keban Baraj Gölü Pertek Bölgesinden alınan yerüstü sularının kalitesinin belirlenmesi amacıyla bazı fizikokimyasal parametrelerden $\mathrm{pH}$, sicaklık ve Eİ değerleri ile $\mathrm{NO}_{3}{ }^{-}-\mathrm{N}, \mathrm{BOİ}_{5}$ ve KOİ konsantrasyonları tespit edildi. Elde edilen veriler 30.11.2012 tarih ve 28483 sayılı Resmi Gazete'de yayınlanarak yürürlüğe giren Yerüstü Su Kalitesi Yönetmeliği’nde (YSKY) belirlenen değerlerle karşılaştırıldı ve tartışıldı. YSKY, yerüstü sular ile kıyı ve geçiş sularının biyolojik, kimyasal, fiziko-kimyasal ve hidromorfolojik kalitelerinin belirlenmesi, sınıflandırılması, su kalitesinin ve miktarının izlenmesi, bu suların kullanım maksatlarının sürdürülebilir kalkınma hedefleriyle uyumlu bir şekilde koruma kullanma dengesi de gözetilerek ortaya konulması, korunması ve iyi su durumuna ulaşılması için alınacak tedbirlere yönelik usul ve esasların belirlenmesi amacıyla çıkartılmıştır [19]. Bu çerçevede, Keban Baraj Gölü Pertek Bölgesinden yaz mevsiminde alınan su örneklerine ait $\mathrm{pH}$, sıcaklık ve Eİ değerleri Şekil 2'de verilmiştir. 

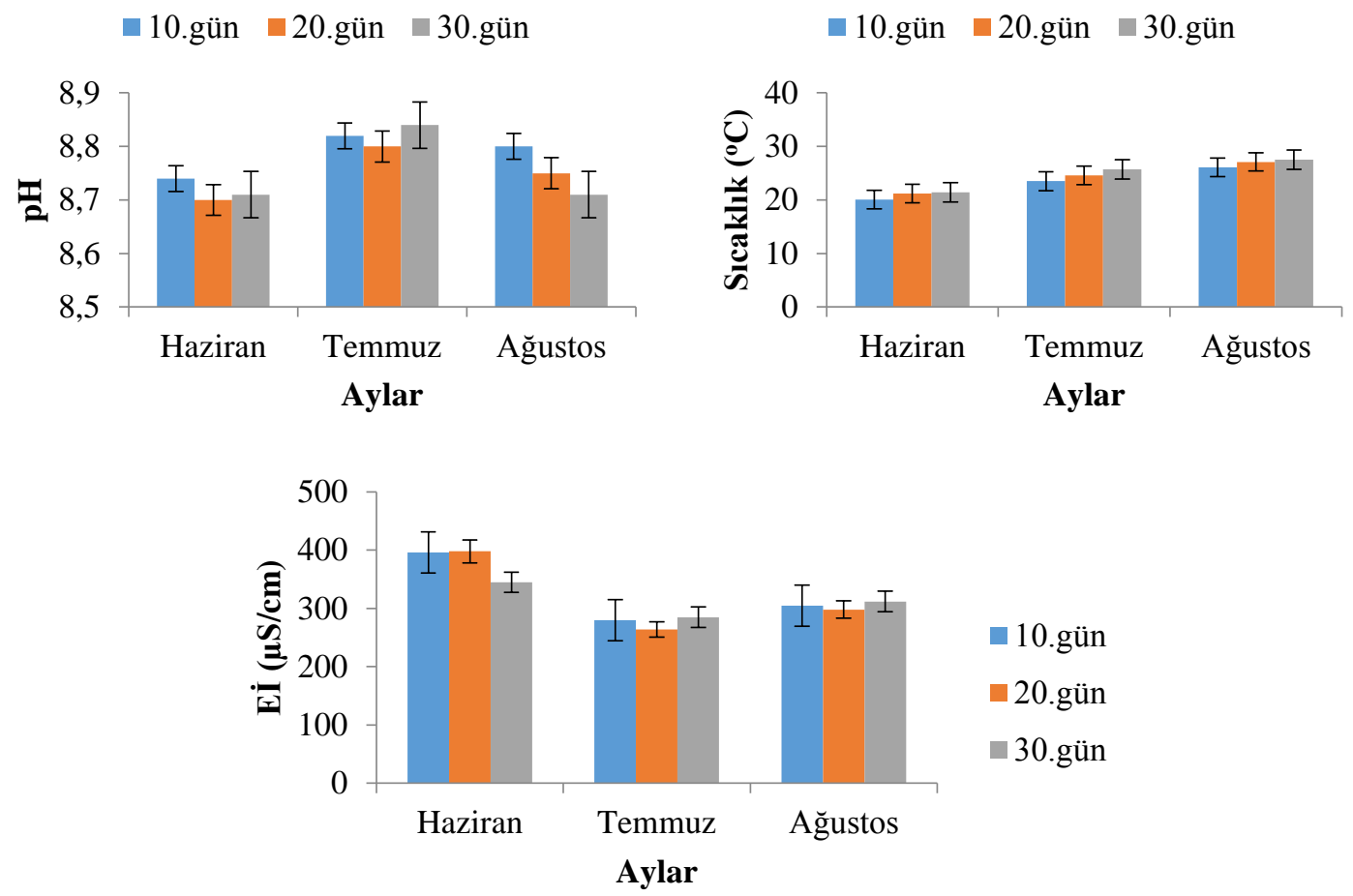

Şekil 2. Keban Baraj Gölü Pertek Bölgesi su örneklerinin pH, sıcaklık ve Eİ değerleri

Şekil 2'ye göre $\mathrm{pH}$ değerleri incelendiğinde $\mathrm{pH}$ değerlerinin 8,7-8,84 arasında değerler aldığ 1 belirlendi. Haziran ayında en yüksek pH değeri 8,74 (10. gün), en düşük pH değeri 8,7 (20. gün) olarak belirlenirken, Haziran ayında ortalama $\mathrm{pH}$ değeri 8,72 olarak tespit edildi. Temmuz ayı incelendiğinde en yüksek pH değeri 30. gün 8,84 olarak, en düşük pH değeri 20. gün 8,8 olarak gerçekleşti. Temmuz ay1 ortalama pH değeri 8,82 olarak hesapland1. A ğustos ayında en yüksek pH değeri 10. gün 8,8 olarak, en düşük $\mathrm{pH}$ değeri 30 . gün 8,71 olarak tespit edildi. Temmuz ayı ortalama $\mathrm{pH}$ değeri 8,75 olarak hesapland. Tunç Dede ve Sezer [20], Aksu Çayında yapmış oldukları çalışmada pH değerlerinin 7,98,1 arasında değiştiğini tespit etmişlerdir. Bu değerler çalışmamızda tespit edilen değerlerden daha düşüktür. Tepe vd. [21] Hatay Hasan Çayında yaptıkları su kalitesi çalışmasında $\mathrm{pH}$ değerinin yaz ve güz ayı ortalamasını 8,6 olarak belirlemişlerdir. Taş [22] Ordu Gaga Gölü'nde yaptığı çalışmada yaz mevsiminde $\mathrm{pH}$ değerini 7,75 olarak tespit etmiştir.

YSKY Ek-5 Tablo 2'de yerüstü su kütlelerinde bazı parametreler için çevresel kalite standartları ve kullanım maksatları başlı̆ğ altında kıta içi yerüstü su kaynaklarının genel kimyası ve fizikokimyasal parametreler açısından sınıflarına göre bir değerlendirme yapılmıştır. Su kalite sınıfları 4 sınıftan meydana gelmiş ve her bir su kalitesi sınıfında parametrelerin hangi aralıklarda olması gerektiği belirlenmiştir. Bu çerçevede, Sınıf-1, Sınıf-2, Sınıf-3 ve Sınıf-4 sular için pH değerlerinin 6-9 arasında olması gerektiği yönetmelikte verilmiştir. Çalışmamızda da $\mathrm{pH}$ değerleri 8,7-8,84 arasında değiştiğinden pH açısından su kalite sınıfı Sınıf-1 olarak belirlenmiştir.

Sıcaklık parametresi incelendiğinde Haziran ayında en yüksek sıcaklık değerinin 30. günde 21,4 ${ }^{\circ} \mathrm{C}$ olarak, en düşük sıcaklık değerinin ise 10 . gün $20,1{ }^{\circ} \mathrm{C}$ olduğu belirlendi. Haziran ayında ortalama sıcaklık değeri $20,9^{\circ} \mathrm{C}$ olarak hesaplandı. Temmuz ayında en yüksek sicaklık değeri 30 . gün $25,7{ }^{\circ} \mathrm{C}$ olarak, en düşük sıcaklık değeri 10 . gün $23,5^{\circ} \mathrm{C}$ olarak belirlendi. Temmuz ayı ortalama sıcaklık değeri $24,6^{\circ} \mathrm{C}$ olarak hesaplandı. Ağustos ayında ise en yüksek sıcaklık değeri 30 . gün $27,5^{\circ} \mathrm{C}$ olarak en düşük sicaklık değeri 10. gün $26,1^{\circ} \mathrm{C}$ olarak tespit edildi. Ağustos ayı ortalama sıcaklık değeri $26,9^{\circ} \mathrm{C}$ olarak hesaplandı. Keban Baraj Gölü Pertek Bölgesi yerüstü sularının yaz mevsimi boyunca sıcaklık değerleri Haziran ayından Ağustos ayına kadar sürekli bir artış gösterdi. Bunun ana nedeni mevsimsel şartlardan dolayı hava sıcaklığının artmasıyla birlikte su sıcaklığında meydana gelen artıştır. Tepe vd [21] Hatay Hasan Çayında yaptıkları su kalitesi çalışmasında sıcaklık değerinin yaz ve güz $16,6{ }^{\circ} \mathrm{C}$ olarak belirlemişlerdir. Taş [22] Ordu Gaga Gölü’nde yaptığı çalışmada yaz mevsiminde sıcaklık değerini 22,1 ${ }^{\circ} \mathrm{C}$ olarak tespit etmiştir. 
Şekil 2'de Eİ değerleri incelendiğinde Haziran ayında en yüksek Eİ değeri 20. gün $398 \mu \mathrm{S} / \mathrm{cm}$ olarak, en düşük Eİ değeri 30. gün $345 \mu \mathrm{S} / \mathrm{cm}$ olarak belirlendi. Haziran ayı ortalama Eİ değeri $380 \mu \mathrm{S} / \mathrm{cm}$ olarak hesaplandı. Temmuz ayında en yüksek Eİ değeri 30. gün $285 \mu \mathrm{S} / \mathrm{cm}$ olarak tespit edilirken, en düşük Eİ değeri 20. gün $264 \mu \mathrm{S} / \mathrm{cm}$ olarak belirlendi. Temmuz ayı ortalama Eİ değeri $276 \mu \mathrm{S} / \mathrm{cm}$ olarak hesapland1. Ağustos ayında en yüksek Eİ değeri 30. gün $312 \mu \mathrm{S} / \mathrm{cm}$ olarak, en düşük Eİ değeri 20. gün $298 \mu \mathrm{S} / \mathrm{cm}$ olarak belirlendi. Ağustos ayı ortalama Eİ değeri $305 \mu \mathrm{S} / \mathrm{cm}$ olarak hesaplandı. Tunç Dede ve Sezer [20] Aksu Çayında yaptıkları çalışmada Eİ değerlerini 155-431 $\mu \mathrm{S} / \mathrm{cm}$ arasında değiştiğini tespit etmişlerdir. Bu değerler çalışmamızda tespit edilen değerlerle benzer değerler göstermiştir. Çalışmamızdaki $\mathrm{pH}$ ve Eİ değerlerinin literatürdeki diğer değerlerden farklı olma sebebi çalışma alanlarının farklı olması, çalışma yapılan bölgelerdeki antropojenik faaliyetlerden ve/veya atık/atıksu gibi deşarjların olması vb. gibi etkenlerden kaynaklanmaktadır.

YSKY Tablo 2'de her bir su kalite sınıfı için Eİ değerleri belirlenmiştir. Buna göre; Sınıf-1 kalitesindeki sular $<400 \mu \mathrm{S} / \mathrm{cm}$, Sinıf-2 kalitesindeki sular 400-1000 $\mu \mathrm{S} / \mathrm{cm}$, Sınıf-3 kalitesindeki sular 1000-3000 $\mu \mathrm{S} / \mathrm{cm}$, Sınıf-4 kalitesindeki sular $>3000 \mu \mathrm{S} / \mathrm{cm}$ olarak sınıflandırılır. Çalışmamızda da yaz mevsimi boyunca Eİ değerleri 264-398 $\mu \mathrm{S} / \mathrm{cm}$ arasında değerler aldığından su kalite sınıfı Sınıf-1 olarak belirlendi.

Keban Baraj Gölü Pertek Bölgesi yaz mevsiminde alınan su örneklerinde tespit edilen $\mathrm{NO}_{3}{ }^{-}-\mathrm{N}$ konsantrasyonları Şekil 3’te verilmiştir.

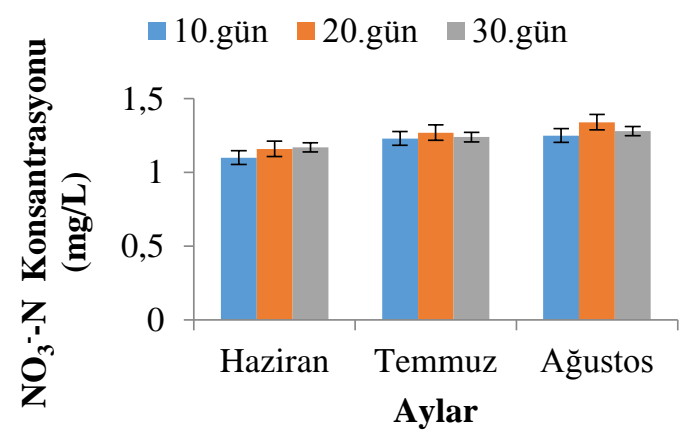

Şekil 3. Keban Baraj Gölü Pertek Bölgesi su örneklerine ait $\mathrm{NO}_{3}{ }^{-}-\mathrm{N}$ konsantrasyonları

Şekil 3'e göre Haziran ayında en yüksek $\mathrm{NO}_{3}^{-}-\mathrm{N}$ konsantrasyonu 30.gün 1,17 mg/L olarak, en düşük $\mathrm{NO}_{3}^{-}-\mathrm{N}$ konsantrasyonu 10 . gün $1,1 \mathrm{mg} / \mathrm{L}$ olarak belirlendi. Haziran ayı ortalama $\mathrm{NO}_{3}{ }^{-}-\mathrm{N}$ konsantrasyonu $1,14 \mathrm{mg} / \mathrm{L}$ olarak hesaplandı. Temmuz ayında en yüksek $\mathrm{NO}_{3}^{-}-\mathrm{N}$ konsantrasyonları 20. gün $1,27 \mathrm{mg} / \mathrm{L}$ olarak en düşük $\mathrm{NO}_{3}^{-}-\mathrm{N}$ konsantrasyonu 10 . gün $1,23 \mathrm{mg} / \mathrm{L}$ olarak tespit edildi. Temmuz ayı ortalama $\mathrm{NO}_{3}^{-}-\mathrm{N}$ konsantrasyonu $1,25 \mathrm{mg} / \mathrm{L}$ olarak hesapland1. Ağustos ayında en yüksek $\mathrm{NO}_{3}{ }^{-}-\mathrm{N}$ konsantrasyonları 20. gün 1,34 mg/L olarak en düşük $\mathrm{NO}_{3}{ }^{-}-\mathrm{N}$ konsantrasyonu 10 . gün $1,25 \mathrm{mg} / \mathrm{L}$ olarak tespit edildi. Ağustos ay1 ortalama $\mathrm{NO}_{3}^{-}-\mathrm{N}$ konsantrasyonu $1,29 \mathrm{mg} / \mathrm{L}$ olarak hesapland1. Yaz mevsiminde $\mathrm{NO}_{3}^{-}-\mathrm{N}$ konsantrasyonları Haziran ayından Ağustos ayına kadar geçen sürede artmıştır. Bunun asıl nedeni antropojenik etkiler (tarımsal faaliyetler vb. gibi) olabileceği düşünülmektedir. Tunç Dede ve Sezer [20], Aksu Çayında yapmış oldukları çalışmada $\mathrm{NO}_{3}{ }^{-}-\mathrm{N}$ konsantrasyonlarının 0,4-1,2 $\mathrm{mg} / \mathrm{L}$ arasında değiştiğini tespit etmişlerdir. Bu değerler çalışmamızda tespit edilen değerlerle benzer sonuçlar göstermiştir. Tepe vd. [21] Hatay Hasan Çayında yaptıkları su kalitesi çalışmasında $\mathrm{NO}_{3}{ }^{-}-\mathrm{N}$ konsantrasyonunun ortalamasını 2,3 mg/L olarak belirlemişlerdir. Bu değerler çalışmamızda tespit edilen değerlerden daha yüksektir. Taş [22] Ordu Gaga Gölü'nde yaptığı çalışmada yaz mevsiminde $\mathrm{NO}_{3}{ }^{-} \mathrm{N}$ değerini $1,06 \mathrm{mg} / \mathrm{L}$ olarak tespit etmiştir. Bu değer çalışmamızda tespit edilen değerlerle benzer sonuçlar göstermiştir.

YSKY Tablo 2'de her bir su kalite sınıfı için $\mathrm{NO}_{3}^{-}-\mathrm{N}$ konsantrasyonları belirlenmiştir. Buna göre; $\mathrm{NO}_{3}{ }^{-}-\mathrm{N}$ konsantrasyonu $<3 \mathrm{mg} / \mathrm{L}$ olan sular Sınıf-1; 3-10 mg/L arasında olan sular Sinıf-2; 10-20 $\mathrm{mg} / \mathrm{L}$ arasında olan sular Sınıf-3 ve $>20 \mathrm{mg} / \mathrm{L}$ olan sular Sınıf-4 olarak belirlenmiştir. Çalışmamızda da yaz mevsimi boyunca $\mathrm{NO}_{3}{ }^{-}-\mathrm{N}$ konsantrasyonlan $3 \mathrm{mg} / \mathrm{L}$ 'den düşük değerler aldığından su kalite sınıfı Sinıf-1 olarak belirlendi.

Keban Baraj Gölü Pertek Bölgesi yaz mevsiminde alınan su örneklerinde tespit edilen BOİ 5 konsantrasyonları Şekil 4'te verilmiştir. 


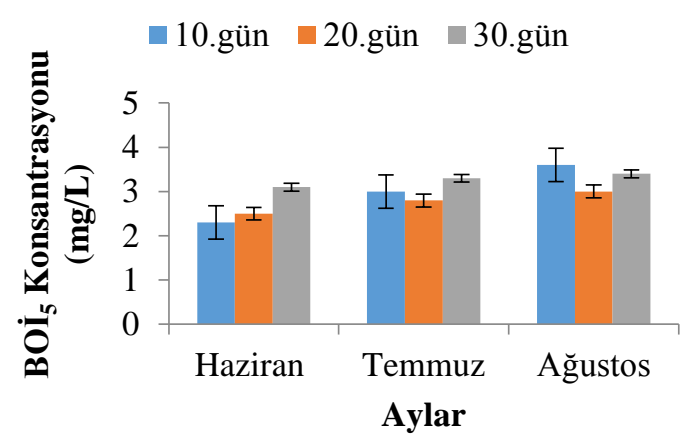

Şekil 4. Keban Baraj Gölü Pertek Bölgesi su örneklerine ait BOİ 5 konsantrasyonları

Şekil 4'e göre Haziran ayında en yüksek BOİ 5 konsantrasyonu 30. gün 3,1 mg/L olarak, en düşük $\mathrm{BOİ}_{5}$ konsantrasyonu 10 . gün $2,3 \mathrm{mg} / \mathrm{L}$ olarak belirlendi. Haziran ayı ortalama $\mathrm{BOI}_{5}$ konsantrasyonu 2,6 mg/L olarak hesaplandı. Temmuz ayında en yüksek BOİ konsantrasyonu 30. gün $3,3 \mathrm{mg} / \mathrm{L}$ olarak en düşük $\mathrm{BOİ}_{5}$ konsantrasyonu 20 . gün $2,8 \mathrm{mg} / \mathrm{L}$ olarak tespit edildi. Temmuz ay1 ortalama $\mathrm{BOI}_{5}$ konsantrasyonu $3,03 \mathrm{mg} / \mathrm{L}$ olarak hesapland. Ağustos ayında en yüksek BOİ 5 konsantrasyonu 10. gün 3,6 mg/L olarak en düşük $\mathrm{BOI}_{5}$ konsantrasyonu 20 . gün $3 \mathrm{mg} / \mathrm{L}$ olarak tespit edildi. Ağustos ayı ortalama BOİ 5 konsantrasyonu $3,33 \mathrm{mg} / \mathrm{L}$ olarak hesaplandı. Yaz mevsiminde BOİ 5 konsantrasyonları Haziran ayından Ağustos ayına kadar geçen sürede artmıştır. Bunun nedeni insan faaliyetleri sonucu göle giren kirleticilerin zamanla artmasından dolayıdır. Tunç Dede ve Sezer [20] Aksu Çayında yapmış oldukları çalışmada $\mathrm{BOİ}_{5}$ konsantrasyonlarının $0,8-1,0 \mathrm{mg} / \mathrm{L}$ arasında değiştiğini tespit etmişlerdir. Bu değerler çalışmamızda tespit edilen değerlerden daha düşüktür.

YSKY Tablo 2'de her bir su kalite sınıfı için $\mathrm{BOI}_{5}$ konsantrasyonları belirlenmiştir. Buna göre; BOİ 5 konsantrasyonu $<4 \mathrm{mg} / \mathrm{L}$ olan sular Sinıf-1; 4-8 mg/L arasında olan sular Sinıf-2; 8-20 mg/L arasında olan sular Sınıf-3 ve $>20 \mathrm{mg} / \mathrm{L}$ olan sular Sınıf-4 olarak belirlenmiştir. Çalışmamızda da yaz mevsimi boyunca $\mathrm{BOİ}_{5}$ konsantrasyonları $4 \mathrm{mg} / \mathrm{L}$ 'den düşük değerler aldığından su kalite sınıfı Sınıf-1 olarak belirlendi.

Keban Baraj Gölü Pertek Bölgesi yaz mevsiminde alınan su örneklerinde tespit edilen KOİ konsantrasyonları Şekil 5'te verilmiştir.

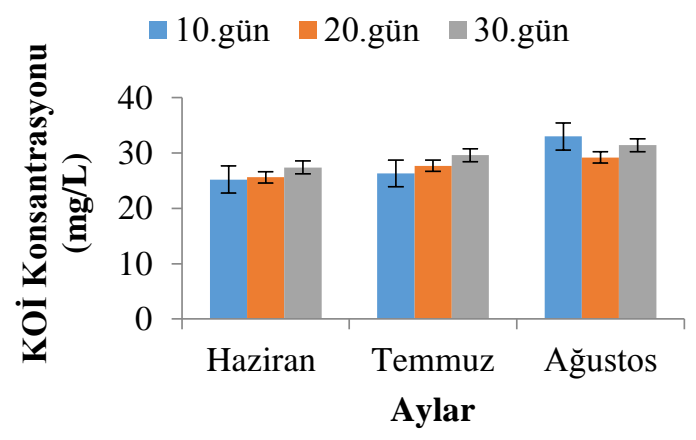

Şekil 5. Keban Baraj Gölü Pertek Bölgesi su örneklerine ait KOİ konsantrasyonları

Şekil 5'e göre Haziran ayında en yüksek KOİ konsantrasyonu 27,4 mg/L (30. gün) olarak, en düşük KOİ konsantrasyonu $25,2 \mathrm{mg} / \mathrm{L}$ (10. gün) olarak belirlendi. Haziran ayı ortalama KOİ konsantrasyonu $26 \mathrm{mg} / \mathrm{L}$ olarak hesaplandı. Temmuz ayında en yüksek KOİ konsantrasyonu 29,6 mg/L (30. gün) olarak en düşük KOİ konsantrasyonu $26,3 \mathrm{mg} / \mathrm{L}$ (10. gün) olarak tespit edildi. Temmuz ay1 ortalama KOİ konsantrasyonu $27,9 \mathrm{mg} / \mathrm{L}$ olarak hesaplandı. Ağustos ayında en yüksek KOİ konsantrasyonu $33 \mathrm{mg} / \mathrm{L}$ (10. gün) olarak en düşük KOİ konsantrasyonu 29,2 mg/L (20. gün) olarak tespit edildi. Ağustos ayı ortalama KOİ konsantrasyonu $31,2 \mathrm{mg} / \mathrm{L}$ olarak hesaplandı. Yaz mevsiminde KOİ konsantrasyonları $\mathrm{BOİ}_{5}$ konsantrasyonlarında olduğu gibi Haziran ayından Ağustos ayına kadar geçen sürede artmıştır. Bunun nedeni $\mathrm{BOİ}_{5}$ parametresinde olduğu gibi insan faaliyetleri sonucu göle giren kirleticilerin zamanla artmasından dolayıdır. Tunç Dede ve Sezer [20], Aksu Çayında yapmış 
oldukları çalışmada KOİ konsantrasyonlarının $6,0-6,5 \mathrm{mg} / \mathrm{L}$ arasında değiştiğini tespit etmişlerdir. Tepe vd. [21] Hatay Hasan Çayında yaptıkları su kalitesi çalışmasında KOİ değerinin yıllık ortalamasını 10,42 $\mathrm{mg} / \mathrm{L}$ olarak belirlemişlerdir. Bu değerler çalışmamızda tespit edilen değerlerden daha düşüktür.

YSKY Tablo 2'de her bir su kalite sınıfı için KOİ konsantrasyonları belirlenmiştir. Buna göre; KOİ konsantrasyonu $<25 \mathrm{mg} / \mathrm{L}$ olan sular Sinıf-1; 25-50 mg/L arasında olan sular Sinif-2; 50-70 mg/L arasında olan sular Sınıf-3 ve $>70 \mathrm{mg} / \mathrm{L}$ olan sular Sınıf-4 olarak belirlenmiştir. Çalışmamızda da Yaz mevsimi boyunca KOİ konsantrasyonları $25-50 \mathrm{mg} / \mathrm{L}$ arasında değerler aldığından su kalite sınıfı Sınıf2 olarak belirlendi.

\section{Sonuç ve Öneriler}

Ülkemizde her bir su kütlesi için su kalitesinin belirlenmesi ve izlenmesi, o su kütlesinin hangi amaçla kullanılıp kullanılamayacağı hakkında bilgi verir. $\mathrm{Bu}$ çalışma kapsamında da önemli su kaynaklarımızdan olan Keban Baraj Gölü'nün Pertek Bölgesinin su kalitesi bazı parametreler açısından belirlenmiş ve YSKY belirlenen değerlerle mukayese edilmiştir. Elde edilen veriler değerlendirildiğinde Keban Baraj Gölü Pertek Bölgesinden alınan yerüstü sularının pH, sıcaklık, Eİ, $\mathrm{NO}_{3}-\mathrm{N}, \mathrm{BOI} 5$ konsantrasyonları açısından Sınıf-1 kalitesinde su olduğu, KOİ açısından ise Sınıf-2 kalitesinden su olduğu tespit edildi. Sonuç olarak Sınıf-1 kalitesindeki sular yüksek kaliteli sular olarak da ifade edilen “çok iyi” su durumunu göstermektedir. Sınıf-1 kalitesindeki sular içme suyu olma potansiyeli yüksek olan yerüstü suları, yüzme gibi vücut teması gerektirenler dahil rekreasyonel maksatlar için kullanılabilir suları, alabalık üretimi için kullanılabilir nitelikte suları ve hayvan üretimi ve çiftlik ihtiyacı için kullanılabilir nitelikteki suları içermektedir. Sınıf-2 kalitesindeki sular ise az kirlenmiş su olarak da ifade edilen "iyi su" durumunu göstermektedir. Sınıf-2 kalitesindeki sular içme suyu olma potansiyeli olan yerüstü sularını, rekreasyonel maksatlar için kullanılabilir nitelikteki suları, alabalık dışında balık üretimi için kullanılabilir nitelikteki suları ve Mer-i mevzuat ile tespit edilmiş olan sulama suyu kalite kriterlerini sağlamak şartıyla sulama suyu olarak kullanılabilecek suları kapsamaktadır. Bu çerçevede, Keban Baraj Gölü Pertek Bölgesinden çekilen suların sulama suyu ve kullanma suyu olarak kullanılması, aynı bölgede alabalık yetiştiriciliği yapılması gibi nedenlerden dolayı su kalitesinde meydana gelebilecek değişimlerin sürekli izlenmesi gerekmektedir. Su kalitesindeki değişimlerin belirlenmesi sadece yaz mevsiminde değil aylık olarak izlenmesi ve mevsimsel değişimlerin su kalitesinde meydana getireceği etkilerinde belirlenmesi gerekmektedir. Özellikle yerüstü sularının kullanıldığı bölgelerde su kaynaklarını kirletme potansiyeli olan kirletici kaynaklarının belirlenmesi de su kalitesi açısından oldukça önemlidir. Bu açıdan incelendiğinde, Keban Baraj Gölü Pertek Bölgesinden hem noktasal hem de yayılı kirletici kaynaklarının belirlenmesi o bölgedeki su kalitesindeki değişimlerinin kirleticiler açısından hangi derecede etkilendiğini gösterebilir. Ancak, Keban Baraj Gölü Pertek Bölgesinde havzanın geniş olması nedeniyle söz konusu yayılı kirletici kaynaklarının belirlenmesi oldukça zor, noktasal kirletici kaynaklarının belirlenmesi daha kolaydır. $\mathrm{Bu}$ bölgedeki noktasal kirletici kaynaklar incelendiğinde yerleşim yerlerinin bulunması ve feribot işletmeciliği yapılması nedeniyle insanlar tarafından farklı şekillerde kirleticilerin sulara bırakılması bu bölgedeki su kalitesinde değişimlere neden olabilmektedir. Bu nedenlerle hem noktasal hem de yayılı kirleticiler belirlendikten sonra gerekli önlemler alınarak Sınıf-2 kalitesinde olan suyun Sınıf-3 ve Sınıf4 kalitesinde bir su olma potansiyelinin ortadan kaldırılması gerekmektedir.

\section{Kaynaklar}

[1] Singh A. 2012. Optimal Allocation of Resources for the Maximization of Net Agricultural Return, Journal of Irrigation and Drainage Engineering, 138 (9): 830-836.

[2] Ali S.A., Tedone L., Mastro G.D. 2015. Optimization of the Environmental Performance of Rainfed Durum Wheat by Adjusting the Management Practices, Journal of Cleaner Production, 87: 105-118.

[3] Liu J., Li Y.P., Huang G.H., Zhuang X.W., Fu H.Y. 2017. Assessment of Uncertainty Effects on Crop Planning and Irrigation Water Supply Using a Monte Carlo Simulation Based Dual-Interval Stochastic Programming Method, Journal of Cleaner Production, 149: 945-967.

[4] Pfister S., Bayer, P. 2015. Monthly Water Stress: Spatially and Temporally Explicit Consumptive Water Footprint of Global Crop Production, Journal of Cleaner Production, 73: 52-62. 
[5] Das B., Singh A., Panda S.N., Yasuda H. 2015. Optimal Land and Water Resources Allocation Policies for Sustainable Irrigated Agriculture. Land Policy, 42: 527-537.

[6] Morillo J.G., Díaz J.A.R., Camacho E., Montesinos P. 2015. Linking Water Footprint Accounting with Irrigation Management in High Value Crops, Jornal of Cleaner Production, 87: 594-602.

[7] FAO, 2015. Food and Agriculture Organization of the United Nations. http://www.fao.org/about/what-we-do/so1/en/. (Erişim tarihi: 1 Mayıs 2016).

[8] Mishra A.K., Kumar B., Dutta J. 2016. Prediction of Hydraulic Conductivity of Soil Bentonite Mixture Using Hybrid-ANN Approach, Journal of Environmental Informatics, 27: 98-105.

[9] FAO, 2006. Agricultural Outlook 2006-2015. Food and Agriculture Organization of the United Nations ftp://ftp.fao.org/docrep/fao/009/a0621e/a0621e00.pdf. (Erişim tarihi: 1 Mayıs 2016).

[10] García-Garizábal I., Causapé J., Merchán D. 2017. Evaluation of Alternatives for Flood Irrigation and Water Usage in Spain Under Mediterranean Climate, CATENA, 55: 127-134.

[11] IPCC. 2007. In: Core Writing Team, Pachauri, R.K., Reisinger, A. (Eds.), Climate Change 2007: Synthesis Report. Contribution ofWorking Groups I, II and III to the Fourth Assessment Report of the Intergovernmental Panel on Climate Change. IPCC, Geneva. 220 p.

[12] IPCC. 2008. Climate Change and Water. Cambridge University Press, Cambridge. 120 p.

[13] EEA. 2012. Water resources in Europe in the context of vulnerability. State of Water Assessment. EEA Report no. 11/2012. European Environmental Agency (EEA), Copenhagen. 100 p.

[14] Iglesias A., Garrote L., Diz A., Schlickenrieder J., Martin-Carrasco F. 2011. Re-Thinking Water Policy Priorities in the Mediterranean Region in View of Climate Change, Environmental Science and Policy, 14: 744-757.

[15] Nunes J.P., Jacinto R., Keizer J.J. 2017. Combined Impacts of Climate and Socio-Economic Scenarios on Irrigation Water Availability for A Dry Mediterranean Reservoir, Science of The Total Environment, 584-585: 219-233.

[16] Collins M., Knutti R., Arblaster J., Dufresne J.L., Fichefet T., Friedlingstein P., Gao X., Gutowski W.J., Johns T., Krinner G., Shongwe M., Tebaldi C., Weaver A.J., Wehner M. 2013. Long-term climate change: projections, commitments and irreversibility. In: Stocker, T.F., Qin, D Plattner, G-K, Tignor M., Allen S.K., Boschung J., Nauels A., Xia Y., Bex, V., Midgley P.M. (Eds.), Climate Change. 2013. The Physical Science Basis. Contribution of Working Group I to the Fifth Assessment Report of the Intergovernmental Panel on Climate Change. Cambridge University Press, Cambridge and New York, $1136 \mathrm{p}$.

[17] García-Ruiz J.M., López-Moreno II., Vicente-Serrano S.M., Lasanta-Martínez T., Beguería S. 2011. Mediterranean Water Resources in A Global Change Scenario, Earth Science Reviews, 105: 121-139.

[18] Kovats R.S.S., Valentini R., Bouwer L.M.L.M., Georgopoulou E., Jacob D., Martin E., Rounsevell M., Soussana J-F.J-F. 2014. Europe. In: Barros V.R., Field C.B., Dokken D.J., Mastrandrea M.D., Mach K.J., Bilir T.E., Chatterjee M., Ebi K.L., Estrada Y.O., Genova R.C., Girma B., Kissel E.S., Levy A.N., MacCracken S., Mastrandrea P.R., White L.L. (Eds.), Climate Change 2014: Impacts, Adaptation, and Vulnerability. Part B: Regional Aspects. Contribution of Working Group II to the Fifth Assessment Report of the Intergovernmental Panel on Climate Change. Cambridge University Press, Cambridge and New York, $1326 \mathrm{p}$.

[19] YSKY. 2010. Yerüstü Su Kalitesi Yönetmeliği, 30.11.2012 Tarih ve 28483 sayılı Resmi Gazete.

[20] Tunç Dede Ö., Sezer M. 2017. Aksu Çayı Su Kalitesinin Belirlenmesinde Kanada Su Kalitesi İndeks (CWQI) Modelinin Uygulanmas1, Journal of the Faculty of Engineering and Architecture of Gazi University, 32 (3): 909-917.

[21] Tepe Y., Ateş A., Mutlu E., Töre Y. 2006. Hasan Çayı (Erzin-Hatay) Su Kalitesi Özellikleri ve Aylık Değişimleri, E.Ü. Su Ürünleri Dergisi, 23: 149-154.

[22] Taş B. 2011. Gaga Gölü (Ordu, Türkiye) Su Kalitesinin İncelenmesi, Karadeniz Fen Bilimleri Dergisi, 1(3): 43-61. 